\title{
Enteroendocrine Cell
}

National Cancer Institute

\section{Source}

National Cancer Institute. Enteroendocrine Cell. NCI Thesaurus. Code C45968.

A hormone-secreting cell present in the epithelium of the intestine. 